\title{
Teaching Video NeuroImages: Susac syndrome's acute onset callosal disconnection
}

Lucas Oliveira Mourão, MD, Jacy Bezerra Parmera, MD, Eduardo de Novaes Costa Bergamaschi, MD, Douglas Mendes Nunes, MD, Ricardo Nitrini, MD, PhD, and Sonia M.D. Brucki, MD, PhD

Neurology ${ }^{\circledR}$ 2020;95:e3161-e3162. doi:10.1212/WNL.0000000000010735

Figure 1 T1-weighted sagittal brain MRI
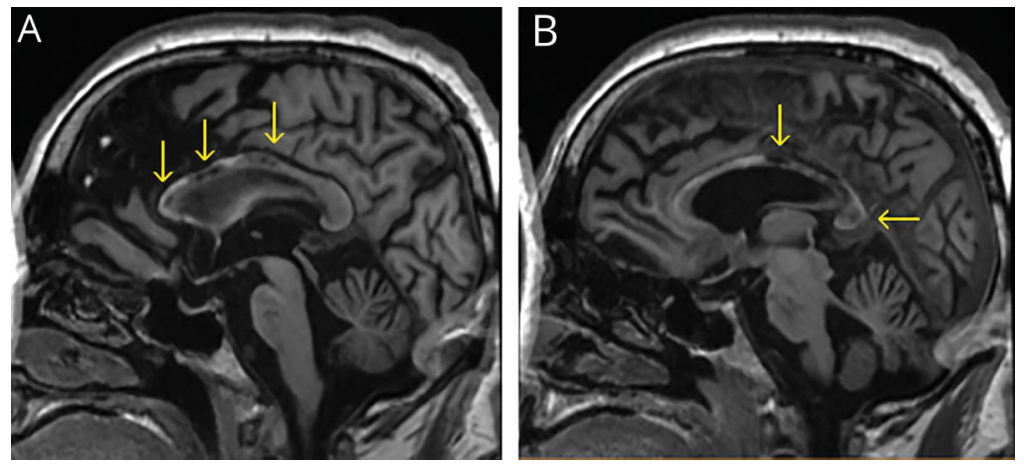

Punched-out holes through the genu (A), corpus (A, B), and splenium (B) of the corpus callosum (yellow arrows). Remarkably, the calloso-septal interface is spared. Although some authors consider this finding pathognomonic of Susac syndrome, Marchiafava-Bignami disease could be a differential diagnosis.

A 59-year-old right-handed hypertensive diabetic and previously alcoholic man presented acute confusional state followed by apathy, dysexecutive syndrome, clumsy left hand, and apraxic gait. A year later, his wife noticed impaired hearing. Neurologic examination revealed marked callosal apraxia (nondominant limb ideomotor apraxia, disconnection variant) and left stereoagnosis due to callosal disconnection (video). Left hand agraphia was present without aphasia. MRI showed punched out holes through corpus callosum, sparing the calloso-septal interface (figure 1). Audiometry revealed left neurosensorial loss. Fluorescein retinography demonstrated hyperfluorescence of arterial vessel wall (figure 2), confirming the hypothesis of Susac syndrome. ${ }^{1}$

\section{Study funding}

No targeted funding reported.

\section{Disclosure}

The authors report no disclosures relevant to the manuscript. Go to Neurology.org/N for full disclosures.

\section{Correspondence}

Dr. Mourão

lucas.omourao@gmail.com

\section{MORE ONLINE}

- Video

$\rightarrow$ Teaching slides

links.lww.com/WNL/

B201 
Figure 2 Retinal fluorescein angiography

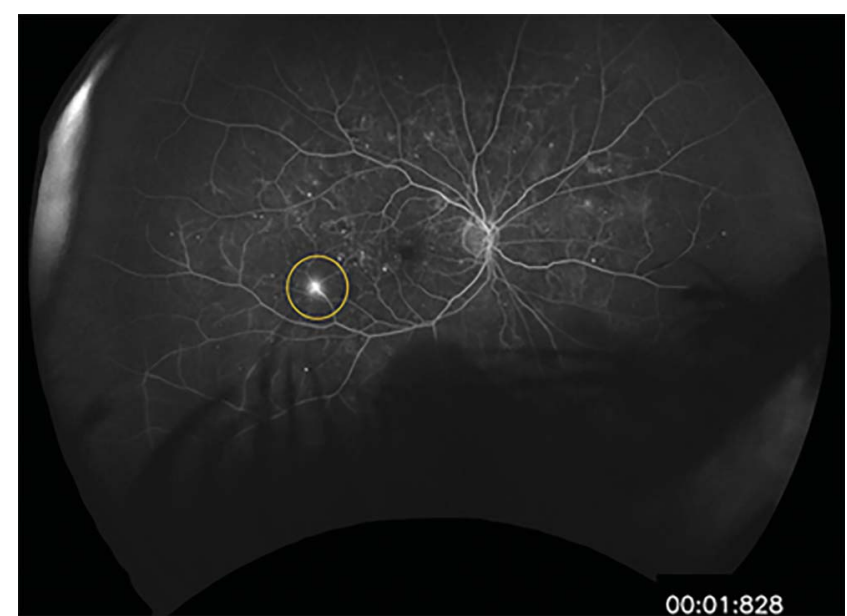

Hyperfluorescence of arterial vessel wall (yellow circle). This examination should be performed whenever there is suspicion of Susac syndrome because patients may not have visual symptoms. Follow-up may be necessary: at disease onset, only $13 \%$ of patients have the Susac triad ${ }^{1}$ (encephalopathy, ${ }^{2}$ neurosensorial loss, and retinal endotheliopathy).

\section{Appendix Authors}

\begin{tabular}{|c|c|c|}
\hline Name & Location & Contribution \\
\hline $\begin{array}{l}\text { Lucas Oliveira } \\
\text { Mourão, MD }\end{array}$ & $\begin{array}{l}\text { University } \\
\text { of São } \\
\text { Paulo }\end{array}$ & $\begin{array}{l}\text { Primary clinical care of the } \\
\text { patient, caption and video } \\
\text { edition, literature review, } \\
\text { drafting and revision of the } \\
\text { manuscript }\end{array}$ \\
\hline $\begin{array}{l}\text { Jacy Bezerra } \\
\text { Parmera, MD }\end{array}$ & $\begin{array}{l}\text { University } \\
\text { of São } \\
\text { Paulo }\end{array}$ & $\begin{array}{l}\text { Primary clinical care of the } \\
\text { patient and revision of the } \\
\text { manuscript }\end{array}$ \\
\hline $\begin{array}{l}\text { Eduardo de Novaes } \\
\text { Costa Bergamaschi, } \\
\text { MD }\end{array}$ & $\begin{array}{l}\text { University } \\
\text { of São } \\
\text { Paulo }\end{array}$ & $\begin{array}{l}\text { Primary clinical care of the } \\
\text { patient and revision of the } \\
\text { manuscript }\end{array}$ \\
\hline $\begin{array}{l}\text { Douglas Mendes } \\
\text { Nunes, MD }\end{array}$ & $\begin{array}{l}\text { University } \\
\text { of São } \\
\text { Paulo }\end{array}$ & Neuroimaging revision \\
\hline $\begin{array}{l}\text { Ricardo Nitrini, MD, } \\
\text { PhD }\end{array}$ & $\begin{array}{l}\text { University } \\
\text { of São } \\
\text { Paulo }\end{array}$ & $\begin{array}{l}\text { Data drafting and revision of the } \\
\text { manuscript }\end{array}$ \\
\hline $\begin{array}{l}\text { Sonia M.D. Brucki, } \\
\text { MD, PhD }\end{array}$ & $\begin{array}{l}\text { University } \\
\text { of São } \\
\text { Paulo }\end{array}$ & $\begin{array}{l}\text { Data drafting and revision of the } \\
\text { manuscript }\end{array}$ \\
\hline
\end{tabular}

\section{References}

1. Kleffner I, Dörr J, Ringelstein M, et al. Diagnostic criteria for Susac syndrome. J Neurol Neurosurg Psychiatry 2016;87:1287-1295.

2. Star M, Gill R, Bruzzone M, De Alba F, Schneck MJ, Biller J. Do not forget Susac syndrome in patients with unexplained acute confusion. J Stroke Cerebrovasc Dis 2015;24:e93-e95. 


\section{Neurology}

Teaching Video NeuroImages: Susac syndrome's acute onset callosal disconnection Lucas Oliveira Mourão, Jacy Bezerra Parmera, Eduardo de Novaes Costa Bergamaschi, et al.

Neurology 2020;95;e3161-e3162 Published Online before print September 9, 2020

DOI 10.1212/WNL.0000000000010735

This information is current as of September 9, 2020

\section{Updated Information \&} Services

References

Permissions \& Licensing

Reprints including high resolution figures, can be found at: http://n.neurology.org/content/95/23/e3161.full

This article cites 2 articles, 1 of which you can access for free at: http://n.neurology.org/content/95/23/e3161.full\#ref-list-1

Information about reproducing this article in parts (figures,tables) or in its entirety can be found online at:

http://www.neurology.org/about/about_the_journal\#permissions

Information about ordering reprints can be found online:

http://n.neurology.org/subscribers/advertise

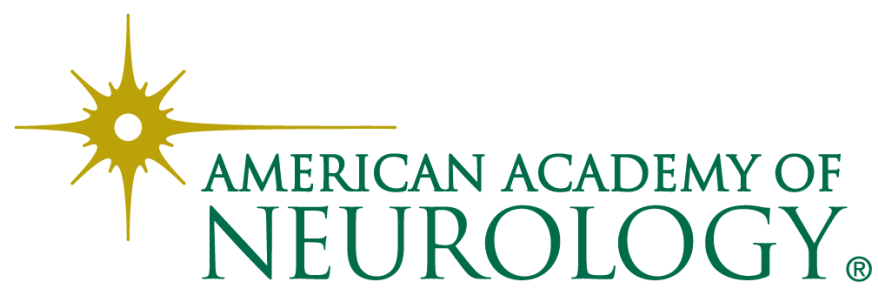

